\title{
Respon Dan Minat Masyarakat Dalam Bertransaksi Untuk Pengembangan Modal Usaha Pada USPPS BMT Al-Ishlah
}

\author{
Abdul Muizz Wadud ${ }^{1 *}$, Muhammad Yahya ${ }^{2}$ \\ IAIN Syekh Nurjati Cirebon \\ 1email: muizzaw15@gmail.com \\ ²email: yahyam@gmail.com \\ *Corresponding Author
}

\begin{abstract}
ABSTRAK
Latar belakang pengabdian ini adalah belum optimalnya pemanfaatan fasilitas pembiayaan untuk pengembangan modal usaha yang disediakan oleh BMT Al-Ishlah. Pengabdian ini bertujuan untuk mengetahui respon dan minat masyarakat pegiat UMKM Plumbon, Kabupaten Cirebon dalam bertransaksi untuk pengembangan modal usaha pada USPPS BMT Al-Ishlah. Metode yang digunakan dalam pengabdian observasi dan wawncara. Subjek dalam pengabdian ini adalah para pegiat UMKM yang berada di sekitar BMT Al-Ishlah Plumbon. Berdasarkan hasil pengabdian, ada yang merespon positif terhadap fasilitas produk pembiayaan yang disediakan, ada juga yang merespon negative. Respon positif yang didapatkan berdasarkan pada kepuasan responden terhadap pelayanan Lembaga dan transaksi yang ditawarkan cenderung menguntungkan. Adapun respon negative didapatkan berdasarkan pada persepsi responden yang menyatakan bahwa bank konvensional dan bank Syariah relative sama dari aspek system transaksi yang digunakan masih mengandung riba.
\end{abstract}

Kata Kunci: Respon dan Minat, Modal, BMT

\begin{abstract}
The background of this dedication is the utilization of financing facilities for the development of venture capital provided by BMT Al-Ishlah did not optimized yet. This dedication aims to know the response and interest of the community of UMKM (Micro Small and Medium Enterprises) Plumbon Cirebon Regency in transacting for business capital development at USPPS BMT AlIshlah. The used methode in this dedication was observation and interview. The subjects in this dedication are UMKM activist who are around BMT Al-Ishlah. Based on the results of this dedication, some respond positively and negatively to the facilities of financing products provided. The positive response based on the respondent's satisfaction with the institution's services and the transactions offered tends to be profitable. The negative response is obtained based on the perception of respondents stating that conventional banks and Islamic banks are relatively equal from aspects of the transaction system used still containing interest.
\end{abstract}

Keywords: Response and Interset, Capital, BMT 


\section{PENDAHULUAN}

Kegiatan perekonomian di Indonesia telah merangsang pertumbuhan sector perbankan. Pada hakikatnya fungsi utama bank sebagai penghimpun dana masyarakat serta penyalurannya kembali kepada yang membutuhkan dalam bentuk kredit. Pengembalian dana yang telah dipinjam oleh nasabah biasanya disertakan dengan bunga secara berkala sampai jatuh tempo. System pembiayaan ini biasa dikenal dengan system konvensional. Adapun system Syariah adalah system yang menjadikan bagi hasil (mudharabah) atau murabahah (profit sharing) sebagai unsur utama pada berbagai jenis transaksi pembiayaan.

Menurut (Setiowati, 2017), pada tahun 1990-an BMT didirikan bersamaan dengan pendirian bank Syariah di Indonesia yang beroperasi dengan prinsip mudharabah (bagi hasil). Lembaga keuangan mikro tersebut semakin berkembang seiring dengan terbitnya kebijakan pemerintah yaitu UU No.7 Tahun 1992 tentang Perbankan dan PP Np.72/1992 tentang Bank Prekreditan Rakyat berdasarkan prinsip bagi hasil.

Berdirinya bank Muamalat Indonesia (BMI), Bank Syariah pertama di Indonesia, memberikan peluang untuk mendirikan Lembaga keuangan Syariah skala mikro seperti Baitul Maal wa Tamwil (BMT). Baitul Maal wa Tamwil merupakan suatu Lembaga keuangan yang memadukan fungsi Baitul Maal dan Baitul Tamwil. Baitul Maal yaitu sebagai Lembaga keuangan syari'ah yang mengarah pada usaha pengumpulan dan penyaluran dana nonprofit seperti akad wadi'ah, zakat, infaq, dan shadaqah. Sedangkan Baitut Tanwil sebagai Lembaga keuangan mikro yang berfungsi untuk pengumpulan dana masyarakat dalam bentuk pinjaman atau pembiayaan usaha dengan system jual beli, bagi hasil maupun jasa (Ridwan, 2005).

Lembaga BMT merupakan Lembaga yang berbentuk koperasi yang berada dalam pengawasan Pusat Inkubasi Bisnis Usaha Kecil (PinbUK). BMT berdiri atas dasar fungsi social berupa pengentasan kemiskinan melalui akad / transaksi Al-qardhul hasan atau pinjaman sukarela, serta fungsi bisnis berupa pembiayaan kepada nasabah yang membutuhkan tambahan modal dengan jumlah tertentu dengan kesepakatan pelunasan pada waktu tertentu ditambah dengan sejumlah imbalan atau bagi hasil ${ }^{1}$.

BMT melayani berbagai nasabah yang bergerak dalam bidang usaha kecil atau UMKM, seperti pedagang sayur, pedagang kelontongan, penarik becak, pedagang asongan, pengrajin kecil, penjahit rumahan, tukang kayu, petani, peternak, serta beberapa usaha atau jasa lainnya yang relative modern. Hal tersebut membuka peluang untuk berkembang lebih pesat di masa mendatang. Namun tantangan dan kendala yang dihadapi dalam operasional BMT terhitung masih banyak.

\footnotetext{
${ }^{1}$ UU No.7 Tahun 1992.
} 
Dalam mengembangkan usaha, para pelaku UMKM sering menghadapi berbagai permasalahan, diantaranya rendahnya SDM, teknologi, terbatasnya sarana dan prasarana, serta terbatasnya akses pembiayaan dan minimnya permodalan. Modal kerja merupakan salah satu faktor perkembangan penjualan. Sehingga sebuah perusahaan atau jenis usaha apa pun jika tidak didukung dengan modal kerja yang kuat, maka ia akan lemah dan akhirya layu. Maka dari itu, dapat dikatakan bahwa modal kerja adalah roda penggerak segala jenis usaha dan kegiatan perekonomian (Chamidun, 2015).

Menurut (Chamidun, 2015) bahwa modal merupakan factor utama yang diperlukan untuk mengembangkan suatu usaha. Berbagai persyaratan administratif dari pihak tidak dapat dipenuhi mengingat terbatasnya modal yang dimiliki para pelaku usaha yang bersifat perorangan. Selain itu, hambatan terbesar yang dihadapi oleh mereka adalah agunan yang dibebankan kepada pelaku usaha, mengingat bahwa tidak semua pelaku UMKM memilki harta yang memadai yang dapat dijadikan sebagai agunan.

Sebagian besar para pengusaha mikro menggunakan sumber keuangan dari rentenir yang memberikan pinjaman dan pembiayaan dengan nilai suku bunga yang tinggi di atas suku bunga pasar. Faktor utama yang menjadikan rentenir sebagai alternatif bagi sebagian besar pelaku UMKM dikarenakan kemudahan prosedur peminjaman yang didapatkan cenderung sederhana dengan tidak menggunakan agunan. Hal tersebut sepatutnya menjadi tanggung jawab BMT dan Lembaga keuangan Syariah lainnya untuk memberikan kemudahan untuk memfasilitasi kelancaran roda usaha setiap pelaku UMKM.

Keberhasilan pembiayaan sangat bergantung pada prosedur pemberian pembiayaan kepada anggota dan masyarakat umum. Mekanisme pembiayaan merupakan ketentuan yang menjamin hak pemberi pinjaman dalam memberikan pinjaman kepada pemnijam agar pinjaman dapat dikembalikan sesuai kesepakatan dengan pemodal atau pemberi pinjaman berikut bagi hasil yang ditetapkan. Dengan demikian prosedur pembiayaan tersebut seyogyanya dijalankan oleh pengurus BMT sehingga pemanfaatan pembiayaan usaha dapat dipertanggung jawabkan demi kelancaran cashflow BMT tersebut.

Pada zaman sekarang, pendapatan masyarakat tidak diiringi dengan jumlah populasi yang berefek pada kebutuhan mereka yang semakin berkembang dan semakin meroket. Padahal jika dilihat keberadaan UMKM sangat berguna dalam pendistribusian pendapatan masyarakat, menciptakan kreativitas, dan menyerap tenaga kerja. Namun, pada kenyataannya pemanfaatan modal yang difasilitasi oleh beberapa Lembaga Keuangan Mikro seperti BMT belum sepenuhnya digunakan secara optimal. Mengingat pemanfaatan teknologi di era digital dapat menjadi wadah bagi masyarakat untuk bekerja dengan modal yang lebih sedikit. 
Berdasarkan pengabdian yang telah dilakukan pada BMT Al-Ishlah serta masyarakat pelaku UMKM di sekitarnya, bahwa minimnya modal masyarakat pelaku UMKM di Plumbon Kabupaten Cirebon mengembangkan usaha mereka menjadi salah satu factor penghambat cashflow dan minimnya pemanfaatan fasilitas pembiayaan BMT Al-Ishlah. Maka dari itu, mereka memerlukan perantara yang dapat memfasilitasi dalam pengembangan usaha mereka, yaitu BMT (Baitul maal wat tamwiil).

Menurut (Ali, 2015), kualitas jasa dengan pelayanan yang optimal yang direfleksikan dalam performa layanan tersebut merupakan salah satu karakter keberhasilan dalam bisnis perbankan. Maka, kualitas pelayanan sangat mempengaruhi perilaku dan kepuasan nasabah atau konsumen. Adapun parameter kepuasan nasabah terhadap pelayanan dapat diukur dalam beberapa aspek diantaranya, aspek wujud fisik, empati, keandalan, daya tanggap, serta aspek jaminan.

Menurut (Wassid, 2011) minat adalah perpaduan antara keinginan dan kemauan yang dapat berkembang. Sedangkan menurut (Wahab, 2004) minat merupakan suatau kecenderungan untuk memberikan perhatian dan bertindak terhadap orang, aktifitas atau situasi yang menjadi objek dari minat tersebut dengan disertai perasaan senang. Dengan kata lain ada suatu usaha (untuk mendekati, menguasai dan berhubungan) dari subyek yang dilakukan dengan perasaan senang, ada daya tarik dari objek.

Pengertian minat menurut Abdul Rahmat Shalih dan Muhbid Abdul Waab adalah seseorang memberikan perhatian terhadap orang, aktifis, situasi yang menjadi objek dengan memahami pada suatu usaha mengetahui secara dalam dan menguasainya. Dari situlah ada daya tarik dan perasaan senang dari objek tersebut.

Sedangkan menurut (Mappiare, 1994), minat merupakan perangkat mental yang terdiri dari suatu campuran dari prasangka, harapan, perasaan yang mengarahkan individu kepada suatu pilihan tertentu. Adapun factor-faktor yang berpengaruh terhadap timbulnya minta yaitu: pertama, factor internal individu yang bersangkutan seperti kemampuan, perasaan, umur, dan pengalaman), sedangkan factor kedua adalah yang timbul dari eksternal individu, seperti keluarga, sekolah, dan masyarakat.

Minat merupakan salah satu faktor yang sangat penting dalam mempengarui preferensi nasabah dalam menabung. Terdapa tiga Batasan minat yakni pertama, suatu sikap yang dapat mengikat perhatian seseorang kearah objek tertentu secara selektif. Kedua, suatu perasaan bahwa aktivitas dan kegemaran terhadap objek tertentu sangat berharga bagi individu. Ketiga, sebagai bagian dari motivasi atau kesiapan yan membawa tingkah laku ke suatu arah atau tujuan tertentu. Maka minat dapat dilihat dari segi aspek perhatian, kesenangan, kegemaran, dan kepuasan sebagai stimulus bagi tindakan dan perbuatan seseorang. Minat juga dipengaruhi pada diri sendiri dan dari 
luar (lingkungan), kenyataannya, factor yang paling dominan berpengaruh bagi nasabah adalah faktor lingkungan (Wassid, 2011).

Menurut (Poerwadaminta, 2006) minat dikelompokkan menjadi 3 bagian, yaitu 1). Berdasarkan timbulnya ada yang bersifat primitif, ada yang bersifat kultural. Adapun minat yang bersifat primitive disebabkan oleh kebutuhan biologis atau jaringan-jaringan tubuh. Sedangkan minat kultural merupakan minat yang timbul disebabkan oleh pengalaman dan proses belajar. 2). Berdasarkan arahnya, minat terbagi menjadi minat intrinsic dan ekstrinsik. Adapun minat intrinsic adalah minat asli individu yang berhubungan langsung dengan aktifitas itu sendiri. Sedangkan minat eksterinsik merupakan capaian atau tujuan akhir dari kegiatan tersebut. 3). Berdasarkan cara mengungkapkan terbagi menjadi empat kategori minat, yaitu Expressed Interest merupakan minat yang dapat diketahui berdasarkan ekspresi yang dinyatakan terhadap kegiatan yang paling digemari hingga yang paling tidak digemari. Manifest Interest merupakan minat yang dapat diketahui dengan cara pengamatan terhadap seseorang melalui aktifitas-aktifitas yang dilakukannya. Tested Interest merupakan minat yang diketahui dengan cara melakukan tes individu yang dihadapkan oleh berbagai pertanyaan, tinggi atau rendahnya skor yang didapatkan mengindikasikan tinggi atau rendahnya minat yang dimiliki. Inventoried test merupakan minat yang dapat diketahui melalui alat yang sudah distandarisasikan dalam berbagai pertanyaan yang berisi apakah ia senag atau tidak senang terhadap aktifitas yang ditanyakan.

Menurut ahli ekonomi modal adalah kekayaan perusahaan yang dapat digunakan untuk kegiatan produksi selanjutnya. Sedangkan pengusaha berpendapat bahwa modal adalah nilai buku dari surat berharga. Modal merupakan faktor produksi yang mempunyai pengaruh kuat dalam mendapatkan produktivitas atau output, secara makro modal merupakan pendorong besar untuk meningkatkan investasi baik secara langsung pada proses produksi maupun dalam prasarana produksi, sehingga mampu mendorong kenaikan produktivitas dan output (Umar, 2000).

Berdasarkan sifatnya modal dapat dibedakan menjadi modal tetap dan modal lancar. Modal tetap adalah modal yang sifatnya tetap, tidak terpengaruh oleh proses produksi dan tidak habis digunakan dalam sekali proses produksi, seperti gedung, mesin-mesin dan alat-alat pengangkutan. Sedangkan modal lancar adalah modal yang habis dalam satu kali proses produksi atau berubah bentuk menjadi barang jadi, seperti bahan baku dan bahan-bahan penolong (Prishardoyo, 2008).

Berdasarkan sumbernya, modal dapat dikelompokkan menjadi:

1. Permodalan sendiri / kekayaan bersih / sumber intern. Sumber ini berasal dari pemilik perusahaan atau bersumber dari dalam perusahaan, seperti penjualan saham, simpanan anggota pada bentuk usaha koperasi, cadangan. Karakteristik dari permodalan sendiri yaitu memiliki keterikatan perusahaan secara permanen. 
2. Permodalan asing / kekayan asing / sumber ekstern. Sumber ini berasal dari pihak luar perusahaan, yaitu berupa pinjaman jangka panjang (dengan jangka waktu lebih dari satu tahun) atau jangka pendek (dengan jangka waktu kurang dari satu tahun). Keistimewaan permodalan ini adalah tidak terikat secara permanen atau hanya sementara yang sewaktuwaktu akan dikembalikan kepada yang meminjamkan (Alma, 2012).

\section{METODE}

Metode yang digunakan yaitu metode kualitatif. Teknik pengumpulan data digunakan melalui Teknik observasi melalui kegiatan workshop produk pembiayaan Syariah USPPS BMT Al-Ishlah, para peserta yang hadir merupakan pegiat UMKM di sekitar BMT Al-Ishlah yang bersifat sebagai responden pada kusioner yang dibagikan pada akhir workshop.

Lokasi pengabdian ini dilakukan di BMT Al-Ishlah Plumbon, Kabupaten Cirebon, Jawa Barat. Target responden pada penelitian ini adalah 20 pegiat UMKM. Selain itu, pengurus BMT juga terlibat dalam memberikan saran pada hasil penelitian ini. Pada penelitian, dokumentasi merupakan sumber data sekunder.

\section{HASIL DAN PEMBAHASAN}

\section{Hasil}

Pada workshop yang diselenggarakan, peneliti berusaha memberikan pemahaman kepada para pegiat UMKM, diawali dengan: (1) pemaparan sejarah BMT di Indonesia, (2) dilanjutkan dengan pemaparan visi BMT Al-Ishlah (Menjadi BMT yang kokoh dengan pelayanan prima, peduli, professional, dan bemranfaat bagi umat, Misi: melakukan pemberdayaan masyarakat melalui Kerjasama usaha dan pengadaan barang modal serta usaha kemitraan lainnya), (3) pemaparan konsep bisnis yang digunakan BMT, (yaitu jasa layanan keuangan dan pembayaran yang fleksibel, pelayanan di tempat nasabah/anggota, Kerjasama dengan perbankan Syariah dalam pembiayaan dan pelayanan jasa pembayaran listrik, telepon, dan jasa lainnya, menjembatani para aghnia untuk membantu kaum dhuafa dengan menjadi amil zakat, infaq, dan shodaqoh), (4) produk-produk simpanan dan pembiayaan yang ditawarkan oleh BMT Al-Ishlah Plumbon kepada para pegiat UMKM, (5) kuisioner singkat untuk mengetahui apakah para peserta sudah memahami konsep Lembaga keuangan Syariah atau BMT dan berminat untuk mengajukan pembiayaan untuk pengembangan usaha bisnis mereka.

Berdasarkan hasil kuisioner yang diajukan diakhir kegiatan workshop tersebut terdapat 17 pegiat UMKM yang sudah memahami betul konsep bisnis Lembaga Keuangan Syariah atau BMT, sehingga berminat untuk mengajukan SIPINTER (Simpanan Pendidikan Terencana) dan 
mengajukan pembiayaan yang ditawarkan BMT sebagai penambahan modal seperti Musyarakah, Murabahah, dan Walimah Mubarokah (Akad Ijarah Mausufah Fii Dzimmah atau IMFZ dengan tujuan untuk memenuhi kebutuhan anggota dalam menyelenggarakan tasyakuran/ walimah/ hajatan/ khitanan atau ulang tahun dan sebagainya) disertai dengan berbagai fasilitas serta kemudahan dalam membayar cicilan.

Selain itu, berdasarkan hasil kuisioner yang diajukan pada akhir workshop, terdapat 3 orang responden belum berminat untuk mengajukan pembiayaan atau simpanan, mereka juga merespon bahwa tidak ada perbedaan antara system bank Syariah dengan konvensional dari segi system yang digunakan yaitu system Riba, hanya penamaan / istilah transaksi yang sedikit berbeda pada Bank Syariah.

\section{Pembahasan}

Berbagai fasilitas dan kemudahan yang ditawarkan oleh BMT Al-Ishlah Plumbon senada dengan penelitian yang telag dilakukan oleh (Karim, 2017) yang menyatakan, bahwa customer Service Officer bank Syariah seyogyanya mengedepankan kecepatan dan kemudahan dalam pelayanan serta komunikasi yang baik.

Menurut (Setiawan, 2015), banyak perusahaan industry atau jasa yang menganggap kualitas pelayanan sebagai unsur utama dalam kompetisi usaha. Hal tersebut sebanding dengan (Suroso dalam Kotler, 2002), bahwa bisnis jasa perbankan merupakan salah satu unsur yang membedakan diri mereka dengan pesaing lainnya. Bisnis perbankan berdiri atas dasar kepercayaan, sehingga keberhasilan usaha sangat ditentukan oleh kualitas pelayanan, karena kualitas pelayanan merupakan bentuk feedback nasabah atau konsumen terhadap tingkat realita pelayanan yang didapatkan dengan pelayanan yang diharapkan oleh para nasabah.

Sedangkan berdasarkan Fiqh Muamalah kualitas pelayanan yang baik berarti menjual jasa pelayanan yang optimal dengan harapan mendapatkan kepuasan konsumen. Maka jasa adalah produk yang diperjual belikan oleh Lembaga dengan harapan agar nasabah mendapatkan hak manfaat dan hak kemudahan bertransaksi. (al-Zuhaily, jilid 4/ hal. 581).

Adapun jika dipandang dari sudut maqashid syari'ah, maka jasa pelayanan yang baik dan optimal sebanding dengan hifzhul 'Irdh (menjaga kehormatan dan martabat manusia), karena manusia adalah makhluk yang mulia dan dimuliakan oleh Allah (Q.S. 17 : 70). Memuliakan manusia adalah sebuah keharusan dan tuntutan dalam syariat Islam, maka salah satu cara untuk menjaga kehormatan manusia yaitu dengan memberikan jasa yang optimal untuk memuliakan manusia dengan cara memberikan kepuasan atas pelayanan jasa yang diberikan, sebagaimana yang telah dilakukan oleh Nabi Muhammad sebagai salah satu pioneer kesuksesan beliau dalam membangun usaha di Kota Mekkah (Antonio, 2018). 
Adapun respon negative yang dihasilkan dari 3 responden disebabkan karena minimnya informasi atau pemahaman yang didapati saat workshop. Hal tersebut tentunya menjadi tanggung jawab BMT untuk memberikan edukasi yang lebih intens mengenai keunggulan - keunggulan produk pembiayaan atau simpanan Lembaga keuangan Syariah.

Febriana 2016, telah melakukan penelitian kepuasan nasabah bank Syariah berdasarkan CARTER (Compliance, Assurance, Reliability, Tangibles, Emphaty, Responsiveness). Hasil penelitiannya menyatakan bahwa pada dimensi Compliance perlu mendapatkan prioritas dari pihak Bank / Lembaga Keuangan untuk diperbaiki. Nasabah yang menilai bahwa pihak bank atau Lembaga keuangan lainnya masih menggunakan system bunga terjadi karena dua hal. Pertama, karena Lembaga keuangan tersebut belum sepenuhnya menerapkan system bagi hasil. Kedua, kurangnya pemahaman nasabah atas transaksi-transaksi yang digunakan oleh Lembaga keuangan atau bank. Apabila system yang digunakan pihak Lembaga keuangan kurang islami, maka perlu diadakan perbaikan system serta evaluasi dalam rangka meningkatkan pemahaman nasabah dan masyarakat dengan memberikan penjelasan yang lebih spesifik terhadap produk-produk atau akadakad yang digunakan serta meyakinkan nasabah bahwa semua produk tersebut sudah berjalan sesuai syariat Islam yang bersandar pada fatwa DSN-MUI.

\section{Strategi BMT Al-Ishlah dalam Peningkatan Minat Masyarakat Terhadap Produk Pembiayaan}

Strategi merupakan suatu perencanaan atau pengelolaan baik sumber daya manusia ataupun segala kinerja didalamnya. Pengelolaan ini bertujuan untuk memperbaiki dan meningkatkan kinerja sehingga minat dan penilaian masyarakat terhadap suatu perusahaan atau lembaga positif. Dalam penelitian yang telah dilakukan terbukti masih kurangnya kepuasan masyarakat terhadap transaksi di Baitul Maal Wa Tamwil Plumbon.

Maka dengan hal ini strategi perlu diterapkan oleh Baitul Maal Wa Tamwil adalah dengan meningkatkan edukasi kepada masyarakat terhadap sistem yang ada didalam bank Syariah. Edukasi ini bertujuan untuk meningkatkan pemahaman dan menghindari kesalahpahaman atas pandangan yang sama terhadap sistem bank Syariah dan bank konvensional. Selain itu strategi yang perlu dilakukan adalah dengan meningkatkan promosi diberbagai media dan pemasarannya, sehingga masyarakat setidaknya mengenal Baitul Maal Wa Tamwil dan memberikan rasa penasaran yang tinggi sehingga masyarakat akan mencoba bertransaksi dan memberikan respon yang positif, dan tentunya menhindari segala bentuk transaksi yang tidak sesuai syariat Islam. 


\section{KESIMPULAN DAN SARAN}

Berdasarkan wawancara dan penelitian yang dilakukan dapat disimpulkan bahwa respon dan minat masyarakat untuk bertransaksi di BMT terbagi menjadi dua, yaitu respon positif karena pelayanan yang diberikan sudah memuaskan dari segi kecepatan dan system yang digunakan dapat merangsang nasabah untuk mengajukan pembiayaan dalam rangka pengembangan usahanya. Kedua adalah respon negative yang menyatakan bahwa semua Lembaga keuangan adalah sama menurut system yang digunakan sehingga tidak ada perbedaan antara Lembaga keuangan islam dan konvensional disebabkan minimnya informasi yang didapatkan oleh masyarakat mengenai keunggulan-keunggulan yang dimiliki Lembaga keuangan Syariah dibandingkan dengan bankbank konvensional.

Maka untuk mengantisipasi permasalahan di atas diperlukan beberapa strategi yang dilakukan oleh BMT, yaitu dengan memaksimalkan promosi diberbagai media sehingga masyarakat lebih mengenal produk serta sistem yang ada didalamnya. Salain itu setrategi yang ada diterapkan adalah dengan meningkatkan edukasi atau pemahaman yang lebih mendalam terhadap masyarakat mengenai produk-produk Syariah, seperti Murabahah, Musyarakah, Mudharabah, IMBT, IMFZ, Muzara'ah dan produk-produk pembiayaan lainnya serta perbedaannya dengan produk pembiayaan di konvensional, sehingga masyarakat memahami sepenuhnya bahwa Lembaga keuangan Syariah adalah Lembaga keuangan murni Syariah yang berjalan di atas koridor dan ketentuan yang ditetapkan dalam Al-Qur'an, Hadits, serta fatwa ulama DSN MUI

\section{UCAPAN TERIMA KASIH}

Penulis mengucapkan banyak terima kasih kepada semua pihak yang telah turut membantu dan berkontribusi mensukseskan kegiatan pengabdian ini, khususnya para pengurus BMT AlIshlah dan para pegiat UMKM di Plumbon. Tak lupa terima kasih dihaturkan kepada IAIN Syekh Nurjati Cirebon yang telah memberikan fasilitas mensukseskan kegiatan pengabdian ini.

\section{DAFTAR PUSTAKA}

Alma, Buchari. (2010). "Pengantar bisnis." Bandung: Alfabeta.

Antonio, Muhammad Syafi'I. (2018). Ensiklopedia Leadership dan Manajemen Muhammad SAW" The Super Leader Super Manager". Tazkia publishing.

Chamidun, Ali. (2015). Analisis faktor-faktor yang mempengaruhi minat umkm mengajukan pembiayaan pada lembaga keuangan syari'ah (studi kasus di bmt barokah magelang). Diss. IAIN Salatiga. 
Febriana, Nina Indah. (2016). Analisis Kualitas Pelayanan Bank Terhadap Kepuasan Nasabah Pada Bank Muamalat Indonesia Kantor Cabang Pembantu Tulungagung. An-Nisbah: Jurnal Ekonomi Syariah, 3(1). 145-168.

Mahmudi, Ali. (2016). Pengaruh Kualitas Produk Tabungan dan Kualitas Pelayanan terhadap Minat Menabung di BMT Tumang Cabang Salatiga. Diss. IAIN SALATIGA.

Mappiare, A. T. (1994). Self-Management sebagai Teknik Mengembangkan Kebiasaan Studi untuk Meningkatkan Prestasi Akademik Mahasiswa. Malang: UBKMI IKIP Malang Depdikbud.

Poerwadarminta, W. J. S. (2006). Kamus Besar Bahasa Indonesiake-3 Edisi. Jakarta: Balai Pustaka.

Prishardoyo, Bambang. (2008). Analisis Tingkat Pertumbuhan Ekonomi dan Potensi Ekonomi Terhadap Produk Domestik Regional Bruto (PDRB) Kabupaten Pati Tahun 2000-2005. JEJAK: Jurnal Ekonomi dan Kebijakan, 1(1).

Rahman, Shaleh Abdul, dan Muhbib Abdul Wahab. (2004). Psikologi Suatu Pengantar dalam Perspektif Islam. Jakarta: prenada media.

Ridwan, Muhammad. (2005). Manajemen Baitul Maal wat Tamwil BMD, Edisi 1.

Setiowati, Nur Eka. (2017). Pengaruh Program Inklusi Keuangan Bmt Al-Falah Terhadap Transaksi Rentenir. Al-Amwal: Jurnal Ekonomi dan Perbankan Syari'ah, 9.1

Umar, Husein. (2000.) Riset Pemasaran \& Perilaku Konsumen. Gramedia Pustaka Utama.

Wassid, Iskandar, and Dadang Sunendar. (2008). Strategi pembelajaran bahasa. Bandung: Remaja Rosdakarya.

Zuhaylī, Wahbah. (1984). al-Fiqh al-Islāmī wa-adillatuh: al-shāmil lil-adillah al-shar‘īyah wa-alārā' al-madhhabīyah wa-ahamm al-naẓarīyāt al-fiqhīyah wa-taḥqīq al-ahạdīth alNabawīyah wa-takhrījuhā wa-fahrasah alfabā' 'ìyah lil-mawḍ̄'āat wa-ahamm al-masā'il alfiqhīyah. Dār al-fikr. 4. 